\title{
Efficiency of sapota leaf extract against aluminium corrosion in a 3 M sodium hydroxide hostile fluid atmosphere: a green and sustainable approach
}

\author{
N RAGHAVENDRA* ${ }^{\circ}$, LEENA V HUBLIKAR, S M PATIL, POOJA J GANIGER \\ and ANJALI S BHINGE \\ Department of Chemistry, K.L.E. Society's P. C. Jabin Science College (Autonomous), Vidyanagar, Hubballi 580031, India \\ *Author for correspondence (rcbhat3@gmail.com)
}

MS received 11 January 2019; accepted 22 April 2019

\begin{abstract}
The present study focussed on the performance of a sapota leaf extract in controlling the aluminium (Al) corrosion in $3 \mathrm{M}$ sodium hydroxide $(\mathrm{NaOH})$ medium thoroughly investigated through gasometric, atomic absorption spectroscopy, electrochemical Tafel diagrams and impedance spectroscopy techniques. The outcome shows that small amounts of the sapota leaf extract are sufficient for the effective mitigation of the $\mathrm{Al}$ corrosion process in $3 \mathrm{M} \mathrm{NaOH}$ solution. The gasometric data revealed that four different concentrations of the plant extract inhibit the Al corrosion process and the protection efficiency of the inhibitor varies with time of the system. Type of inhibition was studied by an electrochemical potentiodynamic polarization technique. The alternating current impedance spectroscopy results show that the plant extract inhibits the corrosion process by forming a defensive layer on the Al surface through an adsorption process, which confirms the inhibition properties of the plant extract. The presence of electron rich groups in the sapota leaf extract was confirmed by the Fourier transform infrared and energy-dispersive X-ray spectroscopy techniques. The particle size of the sapota leaf extract can be analysed by an X-ray diffraction technique. Further, atomic force microscopy and contact angle results evidence the adsorption of the sapota leaf extract on the Al surface. The morphology of the Al surface in protected and unprotected systems was examined through scanning electron microscopy techniques.
\end{abstract}

Keywords. Sapota leaf; atomic force microscopy; Tafel diagrams; impedance spectroscopy; contact angle.

\section{Introduction}

Aluminium (Al) has many industrial and structural applications because of its low-cost and good physical and chemical properties. Aluminium metal is used in various aggressive conditions, such as acid, salt and alkali solutions during several industrial bath operations. Different industrial processes often lead to severe corrosion of $\mathrm{Al}$. The natural protective invisible layer on the Al surface is destroyed when it is exposed to acidic or alkali systems. These solutions increase the corrosion rate of metals due to the presence of corrosive ions. Large economic losses occurred during the process of picking of $\mathrm{Al}$ in industries. The corrosion process can be hindered by several techniques. The corrosion inhibitor is an accustomed technique for the prevention of metal corrosion under aggressive conditions. Corrosion inhibitors are mainly imperative in connection with the alkali cleaning or picking treatment as they applied to the surface of Al. Corrosion inhibitors are the customary chemical substance which, when added to the corrosive atmosphere dramatically blocks the cathodic and anodic reactions [1-4]. Alkali solutions of 40-60\% sodium hydroxide $(\mathrm{NaOH})$ by volume (containing $\sim 1 \%$ inhibitor) are employed at ambient temperature for the removal of dust and rust. $\mathrm{NaOH}$ is generally employed for degreasing purposes. The inhibitors containing oxygen, sulphur, nitrogen and phosphorous mainly retard the corrosion process [2,5-7]. Inorganic, organic and polymeric compounds are traditional inhibitors, but these compounds as corrosion inhibitors are banned in industries because of their venomous, harmful and pricy nature to the environment and human beings. The corrosion inhibitors are selected on the basis of biodegradability, efficiency and economic feasibility. Synthetic compounds are very expensive, hazardous and toxic to nature and they need to be replaced by natural species. Therefore, it is motivated to search for ecological consciousness and safe corrosion inhibitors. Natural extracts are inexpensive, ecologically acceptable, eco-friendly and readily available. Due to toxicity and rarity of some compounds which employed as effective corrosion inhibitors, environmentally friendly compounds are interested. The utilization of different parts of natural species as corrosion inhibitors has been an 
attractive subject for many corrosion researchers. Nowadays, the exploration of green compounds as corrosion inhibitors is highly demanding due to enhanced use of green chemistry in the fields of science and technology. The natural extracts are model eco-friendly candidatures to replace toxic corrosion inhibitors. Lower cost, reduced-environmental risk, high-corrosion inhibition effectiveness and widespread availability make natural species as suitable compounds to replace the toxic and expensive corrosion inhibitors. Therefore, the study of non-toxic compounds as corrosion inhibitors is a consciousness practical approach to beat this hitch. The investigation of green compounds as cheap and non-toxic corrosion inhibitors is an obligatory pasture of study. The literature review shows that different parts of plant extract species (fruit, pulp, bark, stem, root and leaf) have been successfully used as sustainable corrosion inhibitors for different metals in various corrosive environments. The performance of natural extracts as corrosion inhibitors is generally imputed to the presence of organic compounds in their moiety. Polar functions such as $\mathrm{N}, \mathrm{S}, \mathrm{P}$ and $\mathrm{O}$ atoms, double and triple bonds in the organic species are the vital centres for the adsorption on the surface of metal. In the recent past, the organic compounds derived from the plant species have been effectively studied as robust corrosion inhibitors for many metals in various corrosive solutions. Hence, in the present investigation, we focussed on an eco-friendly and cheap inhibitor. The literature study reveals that usually plant compounds are cheap, eco-friendly and possessing a mixture of organic species [8-11]. Entering into the 21 st century, a gigantic range of specific manuscripts about the natural extract as corrosion inhibitors of different electrodes (metals) in the $\mathrm{NaOH}$ system has been published. The corrosion inhibition performance of natural extract species is often attributed to the presence of alkaloids, tannins, polyphenols, proteins, amino acids and carbohydrates. The natural extracts possessing many organic species, each compound having a specific molecular structure. The important plant components are alkaloids, polyphenols, fatty acids, flavonoids and tannins, which effectively block the active metal sites [7,12,13]. In current investigation, corrosion inhibition behaviour of a sapota leaf extract has been investigated. The sapota leaf is aromatic and it has medicinal properties. Hence, in this study, we selected the sapota leaf to evaluate the feasibility of using a cheap, environmentally safe and naturally occurring extract. The sapota leaf extract contains alkaloids, glycosides, saponins, tannins, flavonoids, palmitic acid, oleic acid, linoleic acid, serine, glycine, myricetin-3- $O-\alpha$-1-rhamnoside, myricetin and apigenin-7- $O-\alpha$-1-rhamnoside [14-16]. Due to the presence of electron rich elements in the main group components, the extract of the sapota leaf is considered to be a viable green corrosion inhibitor. The use of the extract of the sapota leaf (figure 1) is expected to reach simultaneously, environmental and indispensable economic goals. The inhibition property of the sapota leaf was confirmed by gasometric, atomic absorption spectroscopy (AAS), Tafel plot, alternating current (AC) impedance spectroscopy, scanning electron microscopy (SEM), and contact angle techniques.

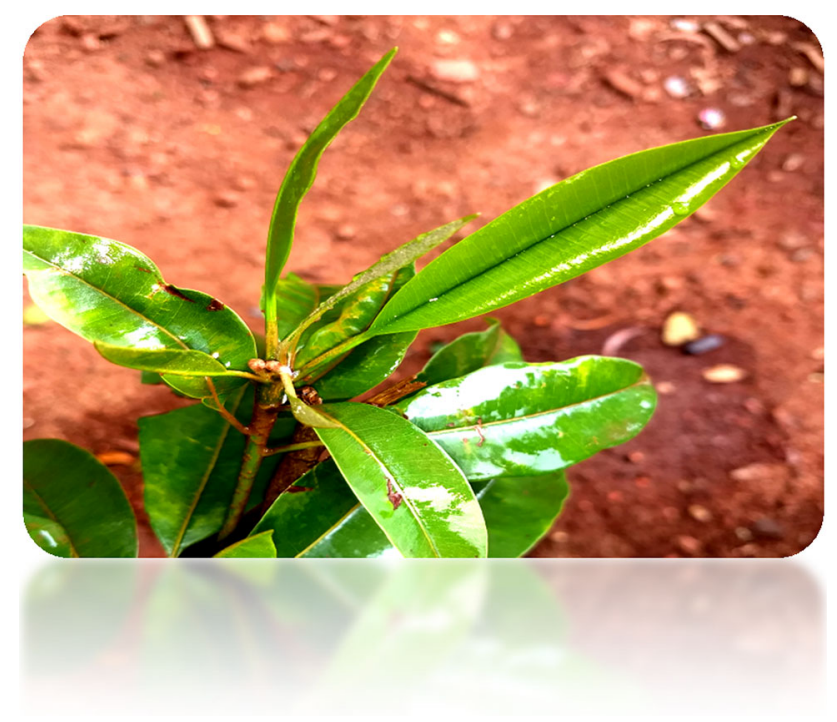

Figure 1. Sapota leaf used in the present investigation.

Characterization of the sapota leaf extract was carried out using X-ray diffraction (XRD), energy dispersive X-ray (EDX) and Fourier transform infrared (FT-IR) techniques. The sapota leaf extract can be used as a noble green corrosion inhibitor that can easily substitute the synthetic one.

\section{Materials and methods}

\subsection{Materials and chemicals}

A $1 \mathrm{~cm}^{2}$ of aluminium (Al-63400) with chemical composition of $0.1 \% \mathrm{Cu}, 0.4-0.9 \% \mathrm{Mg}, 0.6 \% \mathrm{Fe}, 0.2 \% \mathrm{Zn}, 0.2 \% \mathrm{Cr}, 0.3-$ $0.7 \% \mathrm{Si}, 0.3 \% \mathrm{Mn}, 0.2 \% \mathrm{Cr}$ and $0.1 \% \mathrm{Tl}$ and remainder $\mathrm{Al}$ was used in present investigation. Prior to performing the gasometric, AAS, Tafel plot, impedance spectroscopy, SEM, atomic force microscopy (AFM) and contact angle tests, $\mathrm{Al}$ is cleaned with tissue paper and different grades of sand paper. A $3 \mathrm{M}$ $\mathrm{NaOH}$ solution was prepared as per the standard procedure.

\subsection{Preparation of the green corrosion inhibitor}

Dry sapota leaves are collected and washed with double distilled water. A total of $100 \mathrm{~g}$ of the powdered sample extracted with $400 \mathrm{ml}$ of triple distilled water by using the Soxhlet apparatus with an operation time of $8 \mathrm{~h}$. The inhibitor solution is purified and the filtrates were heated on the water bath in order to evaporate the moisture content, finally the dry compound is obtained. The concentration of $0.5,1,1.5$ and $2.0 \mathrm{~g}^{-1}$ was prepared and stored in the refrigerator.

\subsection{Characterization of the sapota leaf extract}

The functional group present in the sapota leaf extract was identified by FT-IR spectroscopy. The percentage of the element present in the sapota leaf was identified by EDX. The 
particle size of the sapota leaf extract can be analysed by using the XRD technique.

\subsection{Gasometric studies}

Compared to the gravimetric technique, the gasometric technique gives more accurate results. Hence, in the present investigation, we selected the gasometric technique. The design of the gasometric technique is shown in Supplementary information. A total of $100 \mathrm{ml}$ of $3 \mathrm{M} \mathrm{NaOH}$ solution was placed in the two-necked flask. In the burette, the initial reading (volume of air) is recorded. The pre-weighed Al metal is weighed approximately and submerged in the $3 \mathrm{M}$ $\mathrm{NaOH}$ solution and the flask is closed by using the stopper. The change in the volume of the gas due to the Al corrosion was monitored by the variation in the paraffin oil in the burette at a fixed time. The study was carried out at $60^{\circ} \mathrm{C}$ using the thermostat water bath. The test was repeated for three times in order to obtain the good reproducible results. The protection rate can be calculated from the below formula:

$$
\text { Corrosion inhibition efficiency }=\frac{V_{\mathrm{a}}-V_{\mathrm{p}}}{V_{\mathrm{a}}},
$$

where $V_{\mathrm{a}}=$ amount of gas liberated in the unprotected system and $V_{\mathrm{p}}=$ amount of gas liberated in the protected system.

\subsection{AAS technique}

AAS was employed in order to estimate the dissolved $\mathrm{Al}$ in $3 \mathrm{M} \mathrm{NaOH}$ solution with different amounts of the sapota leaf extract at a $5 \mathrm{~h}$ immersion period. The protection efficiency can be calculated from the equation below:

$$
\text { Inhibition efficiency }=\frac{B-A}{B} \times 100 \text {, }
$$

where $B=$ amount of dissolved $\mathrm{Al}$ in $3 \mathrm{M} \mathrm{NaOH}$ solution without the inhibitor and $A=$ amount of dissolved $\mathrm{Al}$ in $3 \mathrm{M}$ $\mathrm{NaOH}$ solution with the inhibitor.

\subsection{Electrochemical studies}

Tafel plots and impedance studies are fundamentally employed for determining the protection efficiency of the corrosion inhibitor. Tafel plots and Nyquist plots are measured by using the three electrode cell $(\mathrm{Al}=$ working electrode, $\mathrm{Pt}=$ saturated electrode and calomel $=$ standard electrode). The electrochemical studies were performed at $1 \mathrm{mV} \mathrm{s}^{-1}$ from +250 to $-250 \mathrm{mV}$. Nyquist plots obtained at an amplitude of $10 \mathrm{mV}$.

\subsection{Surface studies}

The effect of $3 \mathrm{M} \mathrm{NaOH}$ solution on the surface of Al degradation and the influence of the sapota leaf extract on the metal surface were evaluated by SEM, AFM and contact angle measurements.

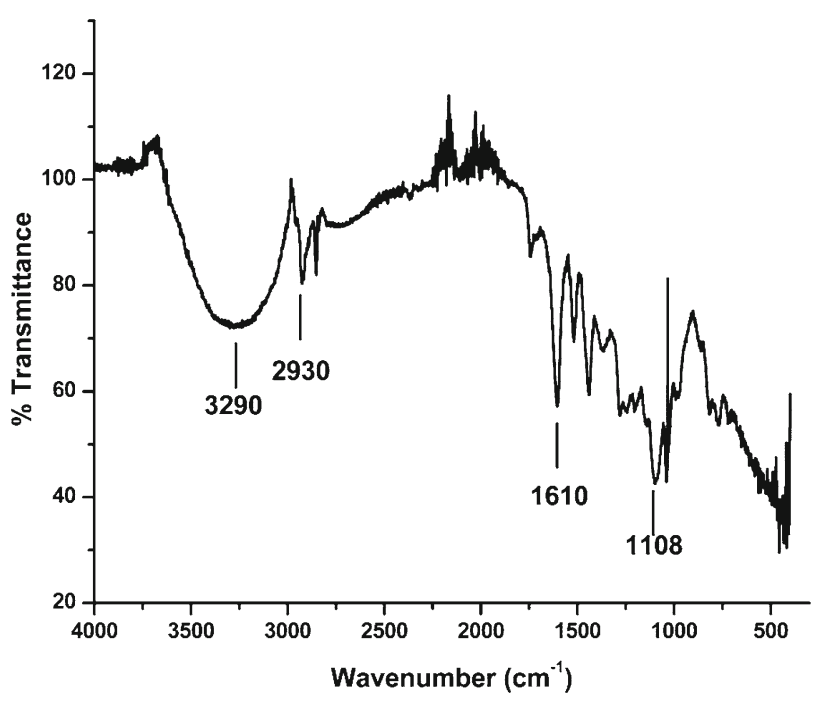

Figure 2. FT-IR spectroscopy of the sapota leaf extract.

Table 1. FT-IR results.

\begin{tabular}{lc}
\hline Bands $\left(\mathrm{cm}^{-1}\right)$ & Groups \\
\hline 3290 & Monomeric hydroxyl \\
1610 & Carbonyl \\
2930 & O-C $=\mathrm{O}$ \\
1108 & $\mathrm{C}-\mathrm{O}$ \\
\hline
\end{tabular}

\section{Results and discussion}

\section{$3.1 \quad$ FT-IR spectroscopy studies}

FT-IR bands identify the structure and components of the organic species. The results of FT-IR spectroscopy of the sapota leave extract is shown in figure 2 and table 1 . This figure and table shows the presence of functional groups in the sapota leaf extract. The functional groups are the electronrich centre, which is expected to be adsorbed on the Al surface in $3 \mathrm{M} \mathrm{NaOH}$ solution and creates a protective thick film on the $\mathrm{Al}$ surface, which act as a barrier for the Al dissolution process.

\subsection{EDX studies}

EDX was used to determine the elemental composition of the sapota leaf extract. The results of EDX are shown in figure 3 and table 2 . The mass composition of oxygen in weight percentage is $40.80 \%$ and in atomic percentage is $34.24 \%$. In addition to this the sapota leaf extract also contains $\mathrm{S}$ atoms. Review of the literature reveals that the compound containing $\mathrm{S}$ and $\mathrm{O}$ atoms in their moieties are expected to show good corrosion inhibition properties on the electrode surface. This confirms that the sapota leaf extract contains electron 


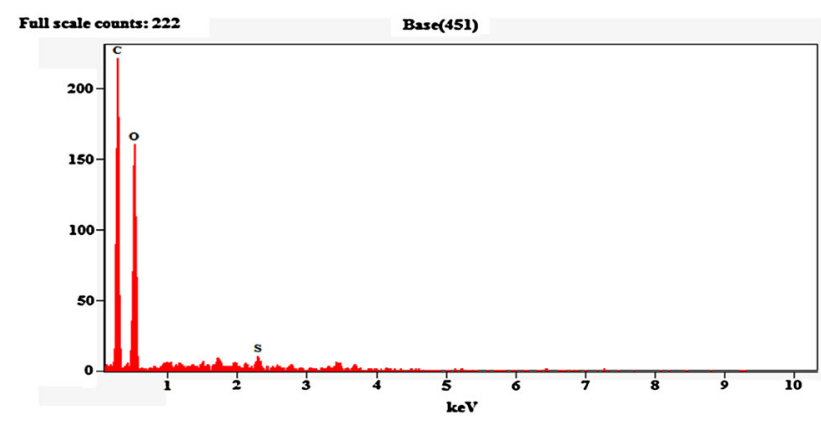

Figure 3. EDX spectra of the sapota leaf extract.

Table 2. Quantitative results of EDX.

\begin{tabular}{lccc}
\hline Element line & Weight $\%$ & Weight\% error & Atom\% \\
\hline C K & 58.60 & \pm 1.13 & 65.51 \\
O K & 40.80 & \pm 1.74 & 34.24 \\
S K & 0.61 & \pm 0.09 & 0.25 \\
S L & - & - & - \\
Total & 100.00 & & 100.00 \\
\hline
\end{tabular}

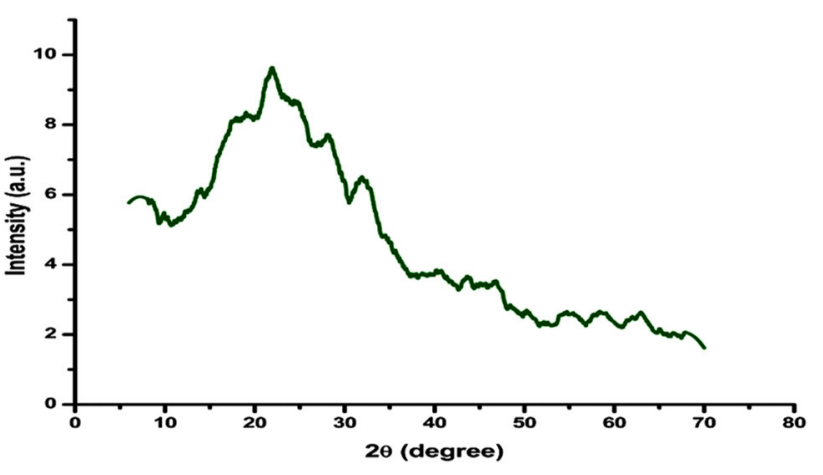

Figure 4. XRD pattern of the sapota leaf extract.

rich elements in a high percentage which is expected to be responsible for the formation of the protective film on the $\mathrm{Al}$ surface in $3 \mathrm{M} \mathrm{NaOH}$ solution.

\subsection{XRD technique}

The XRD technique is used to find the crystal or amorphous nature of the sapota leaf extract. The XRD pattern of the sapota leaf extract is shown in figure 4 . The particle size of the sapota leaf extract is shown in table 3 .

\subsection{Gasometric studies}

The gasometrical technique is one of the broadly used methods for Al corrosion inhibition evaluation. This method estimates the quality of the green inhibitor and quantifies the maximum amount at which the green inhibitor is active under
Table 3. XRD results of the sapota leaf extract.

\begin{tabular}{lcc}
\hline $2 \theta\left(^{\circ}\right)$ & FWHM & Size $(\AA)$ \\
\hline 16.6667 & 0.1 & 838.59 \\
21.5538 & 0.1 & 844.63 \\
\hline
\end{tabular}

Table 4. Gasometric results.

\begin{tabular}{|c|c|c|c|}
\hline Time (in h) & $\begin{array}{l}\text { Concentration } \\
\left(\mathrm{g} \mathrm{l}^{-1}\right)\end{array}$ & Surface coverage & $\begin{array}{l}\text { Protection } \\
\text { efficiency }\end{array}$ \\
\hline \multirow[t]{5}{*}{5} & Blank & & \\
\hline & 0.5 & 0.80 & 80.000 \\
\hline & 1.0 & 0.82 & 82.000 \\
\hline & 1.5 & 0.86 & 86.000 \\
\hline & 2.0 & 0.88 & 88.000 \\
\hline \multirow[t]{5}{*}{10} & Blank & & \\
\hline & 0.5 & 0.78 & 78.662 \\
\hline & 1.0 & 0.80 & 80.085 \\
\hline & 1.5 & 0.81 & 81.507 \\
\hline & 2.0 & 0.84 & 84.352 \\
\hline \multirow[t]{5}{*}{15} & Blank & & \\
\hline & 0.5 & 0.70 & 70.021 \\
\hline & 1.0 & 0.71 & 71.092 \\
\hline & 1.5 & 0.73 & 73.233 \\
\hline & 2.0 & 0.75 & 75.374 \\
\hline \multirow[t]{5}{*}{20} & Blank & & \\
\hline & 0.5 & 0.69 & 69.082 \\
\hline & 1.0 & 0.71 & 71.014 \\
\hline & 1.5 & 0.72 & 72.946 \\
\hline & 2.0 & 0.73 & 73.913 \\
\hline \multirow[t]{5}{*}{25} & Blank & & \\
\hline & 0.5 & 0.66 & 66.804 \\
\hline & 1.0 & 0.67 & 67.634 \\
\hline & 1.5 & 0.68 & 68.464 \\
\hline & 2.0 & 0.70 & 70.954 \\
\hline
\end{tabular}

the existed conditions. The loss in the weight of $\mathrm{Al}$ in the unstirred $3 \mathrm{M} \mathrm{NaOH}$ solution for different immersion times was measured without and with the sapota leaf extract of different concentrations. The results of gasometric studies are shown in table 4. It is observed that the $\mathrm{Al}$ corrosion rate (volume of gas) decreased with a rise in the amount of sapota leaf extract. This nature is due to the adsorption of sapota leaf extract species on the $\mathrm{Al}$ surface in a $3 \mathrm{M} \mathrm{NaOH}$ environment. It was also observed that the protection efficiency was enhanced with the increase in the amount of sapota leaf extract and a stable protective layer was formed on the Al$3 \mathrm{M} \mathrm{NaOH}$ solution interface. These phenomena show that the sapota leaf extract greatly suppresses the Al dissolution by controlling the volume of gas evolution in the corrosive system. A decrease in the $\mathrm{Al}$ corrosion rate with an increase 
in the amount of sapota leaf extract indicates that the inhibition process takes place on the surface of $\mathrm{Al}$ and an extent of Al corrosion inhibition is mainly dependent on the amount of the sapota leaf extract. At lower sapota leaf extract concentrations, the formed film may be a soluble complex, which leads to lower protection efficiency values. At higher sapota leaf extract concentrations, the film formed is an insoluble complex leading to higher protection values due to enhanced coverage. The sapota leaf extract contains $\pi$-electrons and oxygen atoms in their moieties which are good adsorption centres. These adsorption centres retard the penetration of corrosive ions, which is believed to awfully cause metal dissolution. An increase in the adsorption of the sapota leaf extract species on Al metal surfaces effectively separates the metals from corrosive ions. An increase in the contact time from 5 to $25 \mathrm{~h}$ has a negative effect on the protection efficiency, which is due to an unstable protective layer on the Al surface in $3 \mathrm{M} \mathrm{NaOH}$ solution. Due to unavailability of the insoluble film on the metal surface, more $\mathrm{OH}^{-}$ions attack on the aluminium surface which generally accelerates the corrosion processes and enhances the dissolution rate of the substrate. At a higher immersion period, desorption dominates the adsorption process. Therefore, protection efficiency reduces at a higher immersion time.

\section{$3.5 A A S$}

The corrosion of $\mathrm{Al}$ in $3 \mathrm{M} \mathrm{NaOH}$ solution containing four different amounts of the sapota leaf extract was studied by an AAS. The AAS results are shown in table 5. The results of AAS show that the amount of dissolved $\mathrm{Al}$ in $3 \mathrm{M} \mathrm{NaOH}$ solution decreases with a rise in the amounts of the sapota leaf extract. This shows that the sapota leaf extract acts as a green corrosion inhibitor by reducing the attack of $3 \mathrm{M} \mathrm{NaOH}$ solution on the Al surface. An increase in the protection efficiency with a rise in the sapota leaf extract is due to physical or chemical interaction between the $\mathrm{Al}$ surface and green corrosion inhibitor (sapota leaf extract).

\subsection{Tafel plot studies}

The Tafel plot is a significant research tool for the analysis of different electrochemical phenomena. The Tafel plot technique was used in order to understand the kinetics of $\mathrm{Al}$ reactions. Aluminium corrosion behaviour in sodium hydroxide solution without and with different concentrations of sapota leaves are examined by Tafel plot measurement.

The polarization resistance $\left(R_{\mathrm{p}}\right)$ can be determined by the following equation:

$$
R_{\mathrm{p}}=\frac{\beta_{\mathrm{a}} \times \beta_{\mathrm{c}}}{2.303 \times\left[\beta_{\mathrm{a}}+\beta_{\mathrm{c}}\right] \times i_{\text {corr }}},
$$

where $\beta_{\mathrm{a}}=$ anodic Tafel slope, $\beta_{\mathrm{c}}=$ cathodic Tafel slope and $i_{\text {corr }}=$ corrosion current density.
Table 5. AAS results.

\begin{tabular}{|c|c|c|c|}
\hline Time (in h) & $\begin{array}{c}\text { Concentration } \\
\quad\left(\mathrm{g} \mathrm{l}^{-1}\right)\end{array}$ & $\begin{array}{c}\text { Amount of } \mathrm{Al} \\
\text { dissolved in } 3 \mathrm{M} \\
\mathrm{NaOH} \text { solution }(\mathrm{g})\end{array}$ & $\begin{array}{l}\text { Protection } \\
\text { efficiency } \\
\quad \text { (in } \% \text { ) }\end{array}$ \\
\hline \multirow[t]{5}{*}{5} & Blank & 0.060 & \\
\hline & 0.5 & 0.010 & 83.333 \\
\hline & 1.0 & 0.009 & 85.000 \\
\hline & 1.5 & 0.007 & 88.333 \\
\hline & 2.0 & 0.006 & 90.000 \\
\hline \multirow[t]{5}{*}{10} & Blank & 0.090 & \\
\hline & 0.5 & 0.015 & 83.333 \\
\hline & 1.0 & 0.013 & 85.555 \\
\hline & 1.5 & 0.011 & 87.777 \\
\hline & 2.0 & 0.010 & 88.888 \\
\hline \multirow[t]{5}{*}{15} & Blank & 0.100 & \\
\hline & 0.5 & 0.020 & 80.000 \\
\hline & 1.0 & 0.018 & 82.000 \\
\hline & 1.5 & 0.015 & 85.000 \\
\hline & 2.0 & 0.013 & 87.000 \\
\hline \multirow[t]{5}{*}{20} & Blank & 0.130 & \\
\hline & 0.5 & 0.025 & 80.769 \\
\hline & 1.0 & 0.023 & 82.307 \\
\hline & 1.5 & 0.020 & 84.615 \\
\hline & 2.0 & 0.018 & 86.153 \\
\hline \multirow[t]{5}{*}{25} & Blank & 0.150 & \\
\hline & 0.5 & 0.030 & 80.000 \\
\hline & 1.0 & 0.027 & 82.000 \\
\hline & 1.5 & 0.025 & 83.333 \\
\hline & 2.0 & 0.023 & 84.666 \\
\hline
\end{tabular}

The Al corrosion rate can be calculated from the below relation:

$$
\mathrm{Al} \text { corrosion rate }=\frac{0.13 \times i_{\text {corr }} \times E \cdot W}{n d},
$$

where $i_{\text {corr }}=$ corrosion current density $(\mu \mathrm{A}), E \cdot W=\mathrm{Al}$ equivalent weight $(\mathrm{g}), d=\mathrm{Al}$ density $\left(\mathrm{g} \mathrm{cm}^{-3}\right), n=$ number of electrons and $0.13=$ metric and time conversion factor.

The percentage rate in percentage was determined from the below relation:

$$
\text { Protection efficiency }=\left[1-\frac{i_{\text {corr }}^{\prime}}{i_{\text {corr }}}\right] \times 100,
$$

where $i_{\text {corr }}^{\prime}=$ protected $\mathrm{Al}$ corrosion current density and $i_{\text {corr }}$ $=$ unprotected $\mathrm{Al}$ corrosion current density.

Figure 5 shows the Tafel curves for $\mathrm{Al}$ in $3 \mathrm{M} \mathrm{NaOH}$ solution without and with the sapota leaf extract. The results of Tafel plots are presented in table 6 . Addition of the sapota leaf extract to the $3 \mathrm{M} \mathrm{NaOH}$ solution reduces both the $\mathrm{Al}$ corrosion rate and corrosion current values, which implies that corrosion reactions were hindered on the Al surface by the components of the sapota leaf extract. This nature was due to 


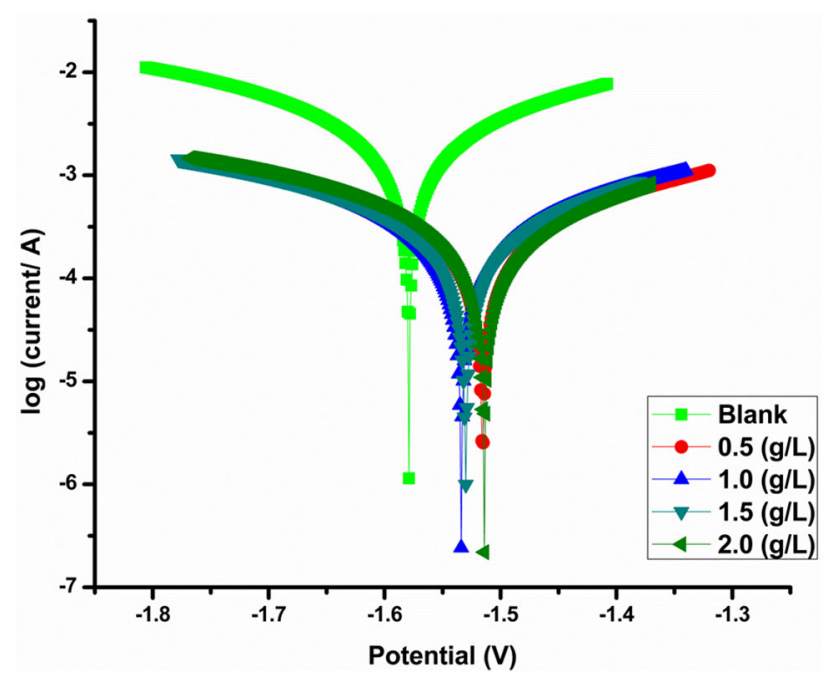

Figure 5. Tafel plots without and four different amounts of the sapota leaf extract.

the protection ability of the surface film formed by the sapota leaf species on the metal surface, which prevents the attack of corrosive ions on electrode surfaces. The adsorption of the sapota leaf extract species usually takes place in the substrate (metal) active sites and hinders the reactivity of the substrate in the dissolution process. This indicates the high protection to $\mathrm{Al}$ in $3 \mathrm{M} \mathrm{NaOH}$ solution. This can be further confirmed by the increase in the protection efficiency and polarization resistance values with an increase in the apota leaf extract concentrations. The Tafel plot study was carried out in order to get the kinetics information of cathodic and anodic reactions of the $\mathrm{Al}$ corrosion process. If the change in the corrosion potential $\left(E_{\text {corr }}\right)$ with a natural inhibitor is more than $85 \mathrm{mV}$, then the inhibitor was classified as anodic or cathodic corrosion inhibitor. Further, if the $E_{\text {corr }}$ value is less than $85 \mathrm{mV}$, then the inhibitor falls under the category of mixed type [17]. In current investigation, there is no significant change in the $E_{\text {corr }}$; cathodic and anodic Tafel slope values clearly hint the mixed corrosion inhibition property of the sapota leaf extract, simultaneously reducing the metal dissolution (anodic contribution) and hydrogen evolution (cathodic contribution) to the aluminium corrosion process. This clearly shows that the studied sapota leaf extract does not only interface the hydrogen evolution, but also interface the dissolution of aluminium metal.

\subsection{Impedance spectroscopy}

Nyquist plots for $\mathrm{Al}$ in an alkali environment without and with different amounts of the sapota leaf extract is shown in figure 6.

ZSimpwin 3.20 software was used for the analysis of Nyquist plots. The electrical circuit used in the present study is shown in figure 7 . The parameters such as double layer

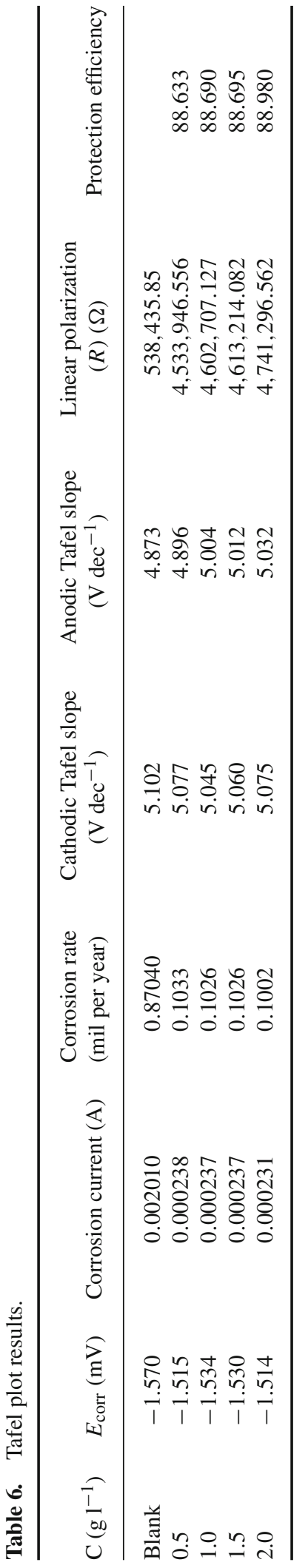




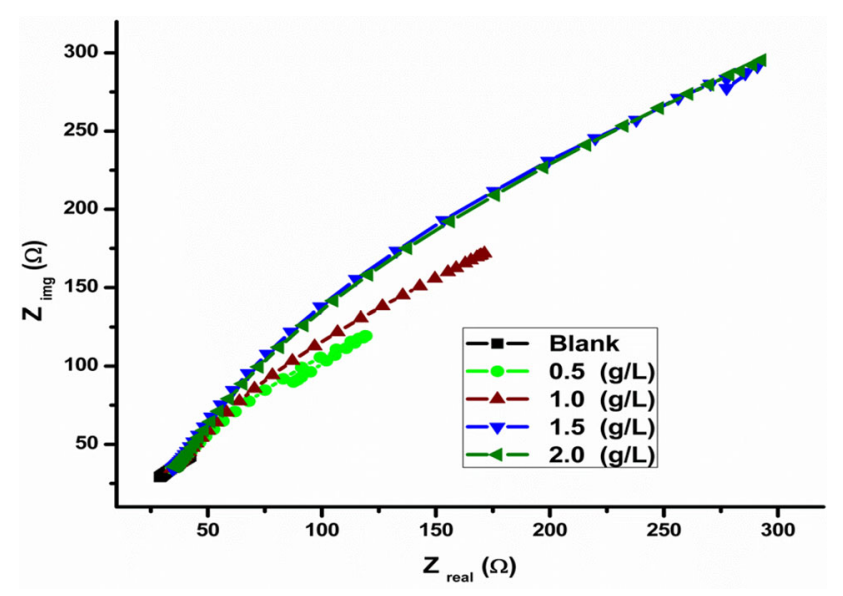

Figure 6. Nyquist plots without and with four different amounts of the sapota leaf extract.

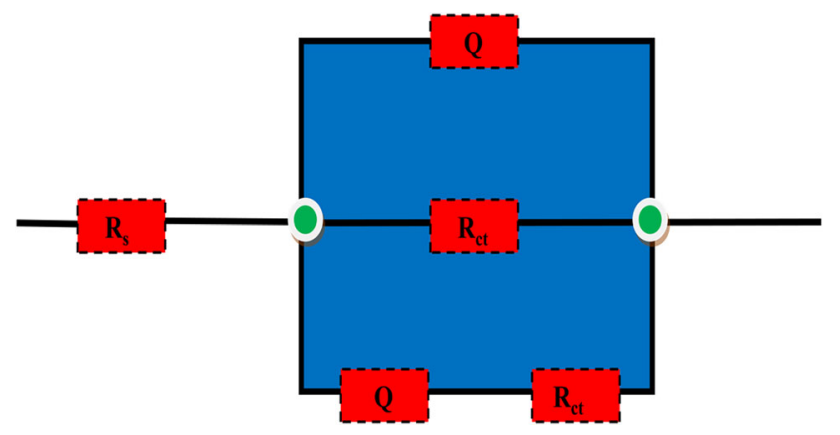

Figure 7. An electrical circuit of model $\mathrm{R}(\mathrm{QR}(\mathrm{QR}))$.

capacitance $\left(C_{\mathrm{dl}}\right)$, constant phase element $(Q)$, CPE exponent $(n)$ and Chi-squared value $\left(\chi^{2}\right)$ are presented in table 7.

The protection rate can be determined by using following relation:

$$
\text { Protection efficiency in } \%=\frac{R_{\mathrm{ct}(\mathrm{inh})}-R_{\mathrm{ct}}}{R_{\mathrm{ct}(\mathrm{inh})}} \times 100,
$$

where $R_{\mathrm{ct}}=\mathrm{Al}$ charge transfer resistance value in the unprotected system and $R_{\mathrm{ct}(\mathrm{inh})}=\mathrm{Al}$ charge transfer resistance value in the protected systems.
The size of the depressed semicircle enhanced with an increase in the sapota leaf concentration, indicated that the sapota leaf extract inhibits the corrosion process primarily by decreasing the conductivity in the solution via the adsorption mechanism with concentration dependent mode. Hence, both $C_{\mathrm{dl}}$ and $Q$ values decrease with a rise in the green inhibitor concentration. Sapota leaf extract molecules decrease the metal surface area available for the corrosion reaction $[4,18$ 20]. An increase in the protection efficiency values with an increase in the concentration of the sapota leaf extract may be attributed to the enhancement in the thickness of the protective layer. The corrosion inhibition role of the sapota leaf extract on the metal surfaces in alkali media takes place by a charge transfer process which is confirmed by observing the $n$ values in the present investigation. The quality of fit was analysed by $\chi^{2}$ values. The obtained Chi-squared $\left(\chi^{2}\right)$ values $(0.000018-0.011060)$ show that impedance results are fitted well with the $\mathrm{R}(\mathrm{QR}(\mathrm{QR}))$ circuit.

\subsection{SEM technique}

The SEM technique was used in order to compare the surface damage in the uninhibited and inhibited system. It will provide the information about the role of the protective film on the metal surface in the inhibited system. In the present study, the SEM micrograph of the surface of aluminium was recorded to observe the changes on the morphology of the metal surface during the corrosion process without and with the sapota leaf extract. The SEM images of $\mathrm{Al}$ in $3 \mathrm{M} \mathrm{NaOH}$ solution without and with the sapota leaf extract species are shown in figure 8. From this, it is clear that the tested $\mathrm{Al}$ is highly damaged in inhibited free solution with a large number of scratches due to a direct attack of $3 \mathrm{M} \mathrm{NaOH}$ solution on the electrode surface, whereas in the inhibited system, the plant extract species blocks the spurt on the Al surface. Hence, the surface become smooth and free from corrosion due to the adsorption of the sapota leaf extract species on the $\mathrm{Al}$ surface, which effectively decreases the interaction between the aluminium and alkali solution resulting in the high protection rate to the electrode surface. Thus, morphological examination by the SEM technique also corroborates the effectual protection of $\mathrm{Al}$ through minimum pits and less damaged in the protected surface. The effectiveness of the sapota leaf extract as a potential corrosion inhibitor may be due to the presence of

Table 7. Nyquist plot results.

\begin{tabular}{lccccccc}
\hline Concentration $\left(\mathrm{g} \mathrm{l}^{-1}\right)$ & $Q\left(\Omega^{-1} \mu \mathrm{s}^{n}\right)$ & $n$ & $R_{\mathrm{ct}}(\Omega)$ & $C_{\mathrm{dl}}(\mu \mathrm{F})$ & Measurement error $(\%)$ & $\chi^{2}$ & $\begin{array}{c}\text { Protection efficiency } \\
(\%)\end{array}$ \\
\hline Blank & 1048.00 & 0.9174 & 13.350 & 985.76 & $<0.4262$ & 0.000018 & \\
0.5 & 1.103 & 0.6239 & 111.00 & 45.390 & $<10.52$ & 0.011060 & 87.972 \\
1.0 & 0.042 & 0.8658 & 176.40 & 74.603 & $<0.7639$ & 0.000058 & 92.431 \\
1.5 & 0.0075 & 1.000 & 300.90 & 77.708 & $<4.177$ & 0.001745 & 95.563 \\
2.0 & 0.0193 & 0.9262 & 310.40 & 75.330 & $<1.071$ & 0.000110 & 95.699 \\
\hline
\end{tabular}




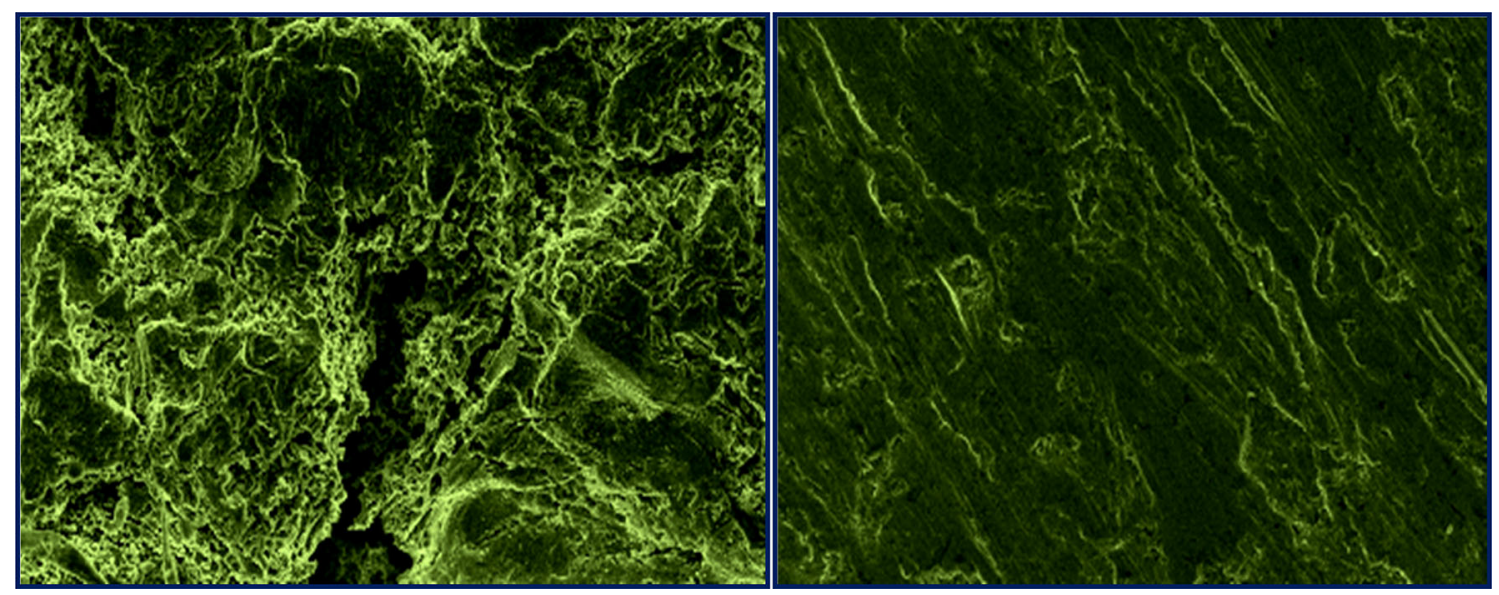

Figure 8. SEM images of $\mathrm{Al}$ in $3 \mathrm{M} \mathrm{NaOH}$ solution without and with the inhibitor.
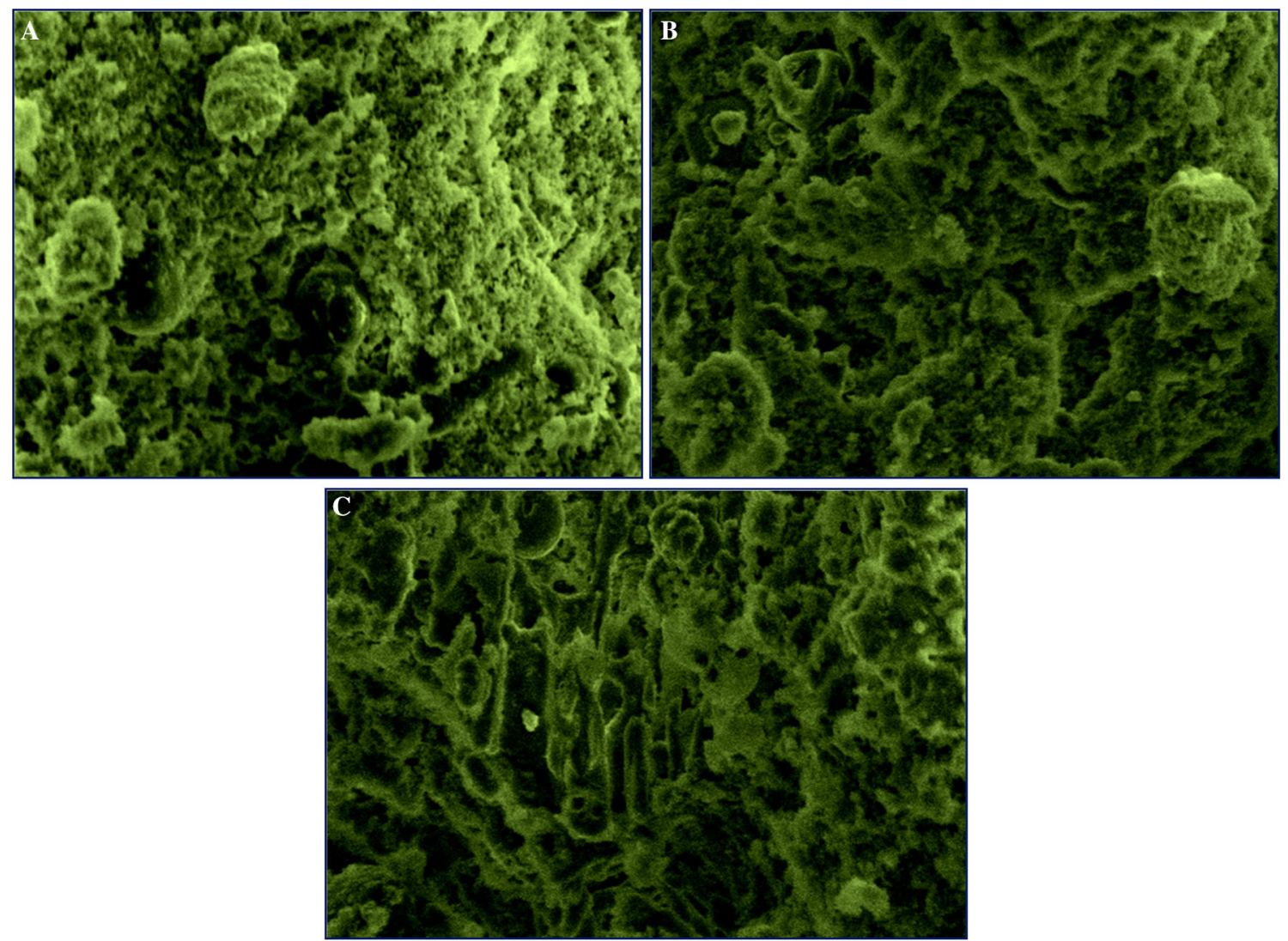

Figure 9. SEM images of (a) sapota leaf extract, (b) sapota leaf extract in $3 \mathrm{M} \mathrm{NaOH}$ solution and (c) sapota leaf extract on the $\mathrm{Al}$ surface in $3 \mathrm{M} \mathrm{NaOH}$ solution.

$\pi$-electrons and lone pair of electrons of oxygen and electron rich atoms. Further, the SEM morphologies of the sapota leaf extract, sapota leaf extract in $3 \mathrm{M} \mathrm{NaOH}$ (in solid form) and scratched powder on $\mathrm{Al}$ are shown in figure 9. The variation in the SEM morphology claimed that the sapota leaf extract can inhibit aluminium in alkali media by the adsorption mechanism.

\subsection{AFM technique}

The surface morphology of $\mathrm{Al}$ in $3 \mathrm{M} \mathrm{NaOH}$ was also examined by the AFM technique. The topography of $\mathrm{Al}$ in $3 \mathrm{M}$ $\mathrm{NaOH}$ solution without and with the sapota leaf extract is shown in figure 10. The results of AFM test are in good agreement with the SEM studies. 


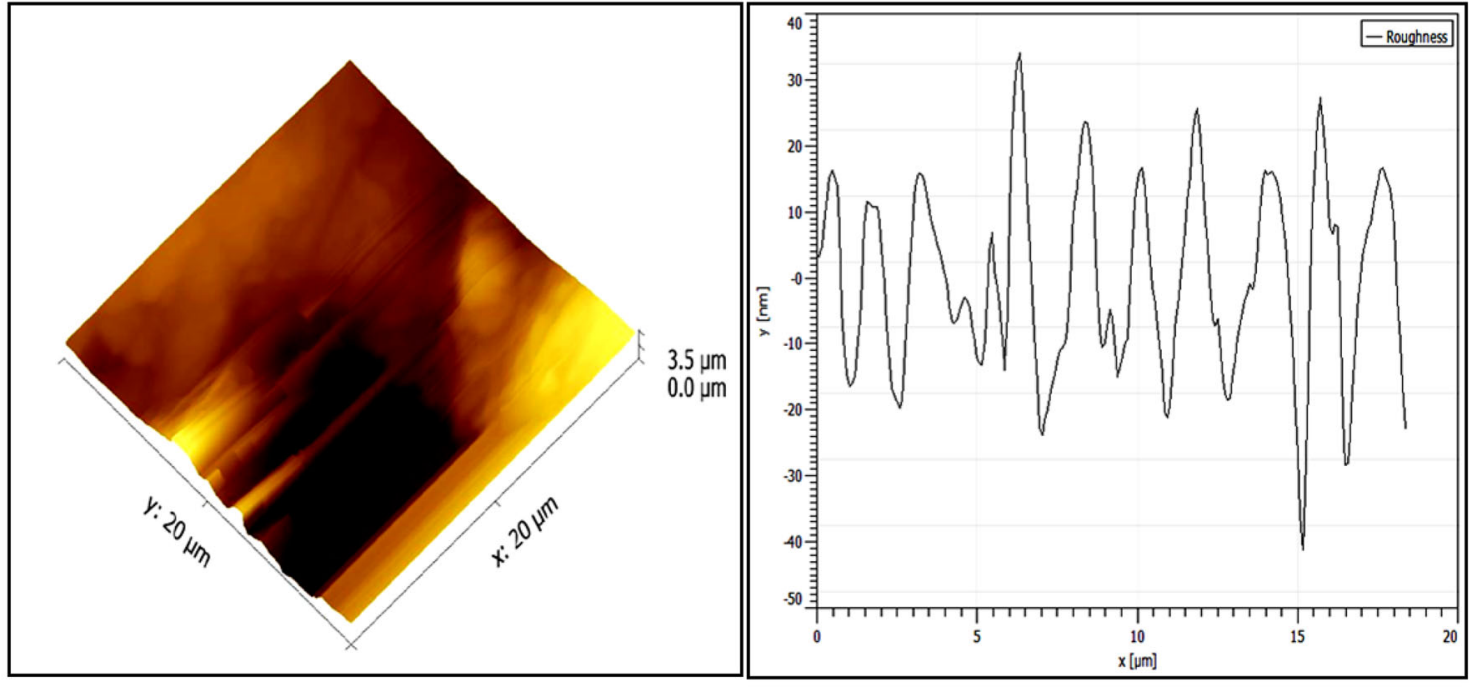

A without inhibitor

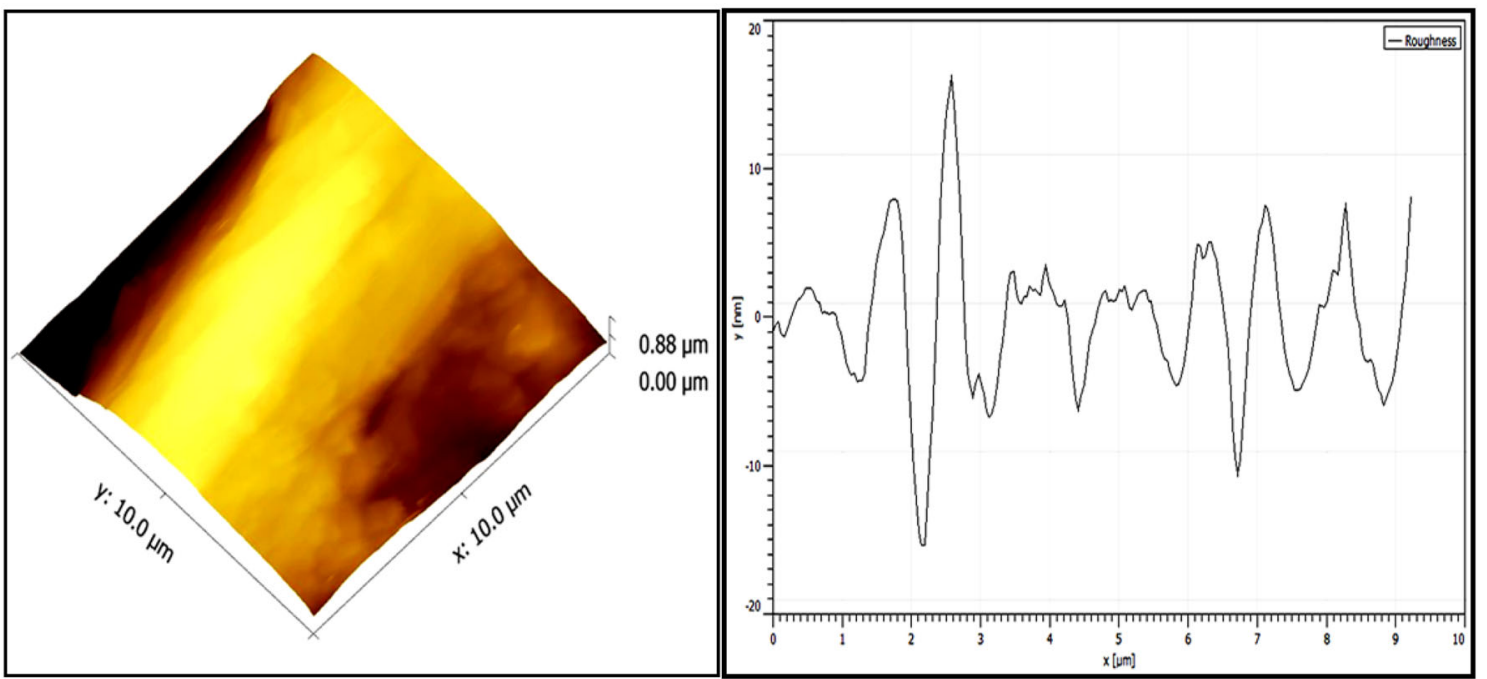

B With inhibitor

Figure 10. AFM images of $\mathrm{Al}$ in $3 \mathrm{M} \mathrm{NaOH}$ solution without and with the inhibitor.

\subsection{Contact angle measurement}

The water contact angle was used to examine the hydrophobicity of the invisible protective layer on the metal surface. The surface chemistry of $\mathrm{Al}$ submerged in $3 \mathrm{M} \mathrm{NaOH}$ solution without and with the sapota leaf extract was studied by the contact angle test. The results of the contact angle test are shown in table 8 and figure 11. Table 8 and figure 11 show that enhancement in the contact angle from bare solution to inhibited solution is an indication of a reduction in surface hydrophilicity. The adsorption of the sapota leaf extract on $\mathrm{Al}$ in $3 \mathrm{M} \mathrm{NaOH}$ solution is responsible for the enhancement
Table 8. Contact angle results.

\begin{tabular}{lcc}
\hline Trial number & $\begin{array}{c}\text { Contact angle }\left(^{\circ}\right) \\
\text { Blank }\end{array}$ & $\begin{array}{c}\text { Contact angle }\left({ }^{\circ}\right) \\
2 \mathrm{~g}^{-1} \text { of sapota leaf } \\
\text { extract }\end{array}$ \\
\hline 1 & 73.5 & 87.5 \\
2 & 73.9 & 86.7 \\
3 & 79.4 & 91.7 \\
4 & 79.3 & 92.0 \\
5 & 78.9 & 94.6 \\
6 & 62.5 & 91.8 \\
\hline
\end{tabular}



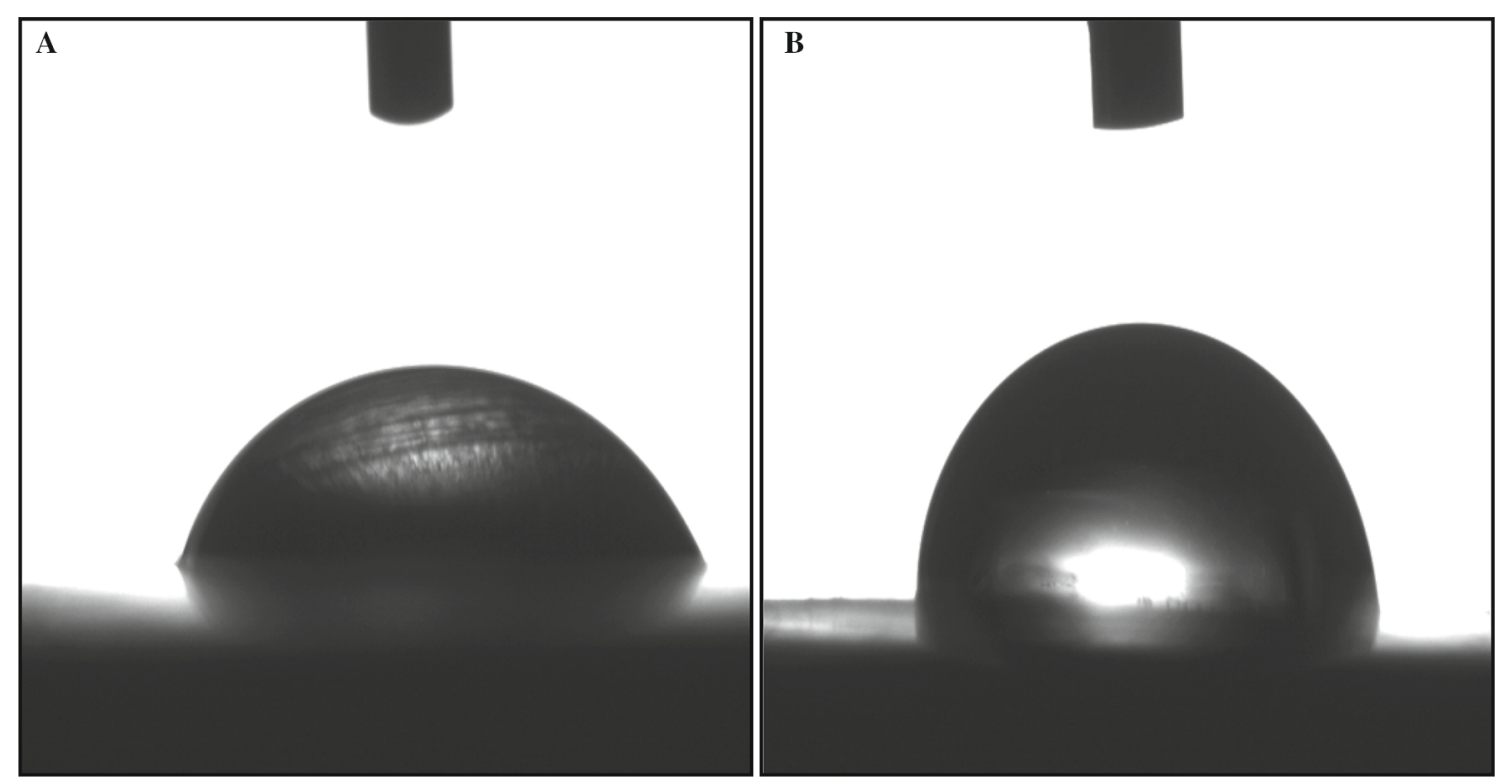

Figure 11. Contact angle test results of $\mathrm{Al}$ dipped in $3 \mathrm{M} \mathrm{NaOH}$ solution without and with $2 \mathrm{~g} 1^{-1}$ of sapota leaf extract (a) blank-73.5 and (b) $2 \mathrm{~g}^{-1}$ of sapota leaf extract- $87.5^{\circ}$.

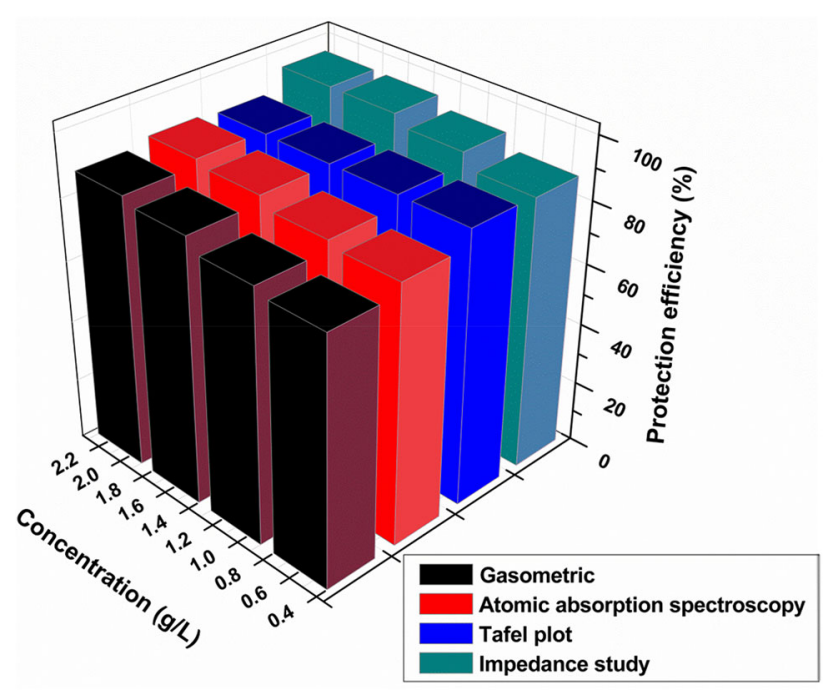

Figure 12. Protection efficiency of the sapota leaf extract obtained from different techniques.

in the contact angle. The increase in the contact angle indicates that the sapota leaf extract successfully adsorb on $\mathrm{Al}$ in $3 \mathrm{M} \mathrm{NaOH}$ solution and inhibit the dissolution process. The protective layer renders the surface of hydrophobic aluminium and so blocks the corrosion process. The results of the contact angle are shown in supporting information.

\subsection{Comparison}

A total of $95 \%$ is the maximum protection efficiency of the sapota leaf extract on the $\mathrm{Al}$ surface in the $3 \mathrm{M} \mathrm{NaOH}$ solution observed through Nyquist plot studies. James et al [21] reported that $97 \%$ is the maximum protection efficiency at $30^{\circ} \mathrm{C}$ for two hours immersion time with $52 \% \mathrm{~V} / \mathrm{V}$ of Gossypium leaf extracts through a weight loss technique. The protection efficiency obtained from the current study is different from the literature value. The different techniques, conditions, temperatures and times may be the main reason for the observed deviation in the corrosion inhibition efficiency values. Further, the weight loss technique reports the average values, whereas impedance studies give instantaneous values. The chemical composition of Gossypium leaf extracts is different from the sapota leaf extract; this is also the main reason for the observed deviation in the corrosion protection efficiency values. The protection efficiency of the sapota leaf extract by different techniques on the $\mathrm{Al}$ surface in $3 \mathrm{M} \mathrm{NaOH}$ solution was shown in figure 12 .

\section{Conclusions}

The gasometric results show the potential corrosion inhibition property of the sapota leaf extract on aluminium in alkali media. The protection efficiency is directly proportional to the amount of the sapota leaf extract and inversely proportional to the substrate (metal) immersion time. The maximum protection efficiency was achieved at $2 \mathrm{~g}^{-1}$ of the sapota leaf extract with an immersion time of $5 \mathrm{~h}$. The presence of electron rich elements in the sapota leaf extract was confirmed by FT-IR and EDX results. The crystal nature of the sapota leaf extract can be confirmed by XRD. The AAS results show that sapota leaf extract species adsorbed on aluminium in alkali solution decreases the solubility of $\mathrm{Al}$ in the $3 \mathrm{M} \mathrm{NaOH}$ solution. Tafel curves indicated that the sapota leaf extract species adsorb on the both anodic and cathodic areas of aluminium in 
alkali media and blocks the corrosion process by mixed mode (means that the sapota leaf extract species act as a mixed corrosion inhibitor for aluminium in alkali media). Further, AC impedance spectroscopy, SEM and AFM interpretation of the aluminium surface showed the protective role of sapota leaves on the substrate surface in alkali media. The reduction in the surface hydrophilicity observed in the contact angle test indicates the adsorption of the sapota leaf extract on the active sites of $\mathrm{Al}$ in a $3 \mathrm{M} \mathrm{NaOH}$ environment. From these, it can be concluded that species of the sapota leaf extract can be employed as a potential corrosion inhibitor for aluminium in alkali media.

\section{References}

[1] Saxena A, Prasad D and Haldhar R 2018 J. Mater. Sci. 53224

[2] Oguzie E E 2007 Corros. Sci. 491527

[3] Abiola O K and Otaigbe J O E 2009 Corros. Sci. 512790

[4] Oguzie E E 2009 Chem. Eng. Commun. 196591

[5] Raghavendra N and Bhat J I 2018 Chem. Eng. Commun. 205 145

[6] Elgahawi H, Gobara M, Baraka A and Elthalabawy W 2017 J. Bio. Tribo. Corros. 355
[7] Eddy N O, Odoemelam S A and Odiongenyi A O 2009 J. Appl. Electrochem. 39849

[8] Raja P B and Sethuraman M G 2008 Mater. Lett. 62 113

[9] Abiola O K and James A O 2010 Corros. Sci. 52661

[10] El-Etre A Y 2003 Corros. Sci. 452485

[11] Gunasekaran G and Chauhan L R 2004 Electrochim. Acta 49 4387

[12] De Souza F S and Spinelli A 2009 Corros. Sci. 51642

[13] Ansari K R, Quraishi M A and Singh A 2014 Corros. Sci. 795

[14] Mital K and Sumitra C 2012 Asian Pac. J. Trop. Biomed. 2 S1526

[15] Fayek N M, Abdel Monem A R, Mossa M Y, Meselhy M R and Shazly A H 2012 Phcog. Res. 485

[16] Ganguly A, Al Mahmud Z, Saha S K and Abdur Rahman S M 2016 Pharm. Biol. 541413

[17] Pavithra M K, Venkatesha T V, Punith Kumar M K and Tondan H C 2012 Corros. Sci. 60104

[18] Abiola O K, Otaigbe J O E and Kio O J 2009 Corros. Sci. 51 1879

[19] Muller M 2004 Corros. Sci. 46159

[20] Subramanyam N C, Sheshadri B S and Mayanna S M 1993 Corros. Sci. 34563

[21] James A O, Oforka N C and Abiola O K 2006 Bull. Electrochem. 22111 